\title{
IMPLEMENTASI E-LEARNING DENGAN MODEL PACE BERBANTUAN MODUL BERBASIS MASALAH PADA KONDISI PANDEMIC COVID-19
}

\author{
Yusfita Yusuf ${ }^{1}$, Hardi Suyitno ${ }^{2}$, Y.L. Sukestiyarno ${ }^{3}$, Isnarto ${ }^{4}$, Agus Jaenudin ${ }^{5}$ \\ STKIP Sebelas April 1,5 \\ Universitas Negeri Semarang $2,3,4$ \\ Email: yusfitayusuf87@gmail.com ${ }^{1}$, hhardisunnes@yahoo.com ${ }^{2}$, \\ sukestiyarno@gmail.com ${ }^{3}$, isnarto.math@mail.unnes.ac.id ${ }^{4}$, \\ agusjaenudin1975@gmail.com ${ }^{5}$
}

\begin{abstract}
Abstrak. Situasi pandemi Covid-19, membuat pemerintah memberikan anjuran untuk belajar di rumah, oleh sebab itu e-learning dijadikan sebagai alternatif pelaksanaan pembelajaran. Pada e-learning perlu ditetapkan tujuan pembelajaran, model pembelajaran serta media pembelajaran yang digunakan untuk menyampaikan bahan ajar. Oleh karena itu, digunakan model pembelajaran PACE berbantuan modul berbasis masalah dengan tujuan pembelajaran penalaran statistis. Tujuan dari penelitian ini adalah untuk mengetahui pelaksanaan e-learning dengan model PACE berbantuan modul berbasis masalah pada perkuliahan statistika dalam kondisi pandemic Covid-19 dan efectivitas dari dari e-learning dengan model PACE berbantuan modul berbasis masalah pada perkuliahan statistika terhadap penalaran statistis. Adapun metode penelitian yang digunakan adalah metode deskriptif dengan sampel 24 orang mahasiswa yang mengambil mata kuliah statistika penelitian. Hasil penelitian menunjukkan bahwa pelaksanaan e-learning dengan model PACE berbantuan modul berbasis masalah pada perkuliahan statistika dalam kondisi pandemic Covid-19 dapat dilaksanakan sesuai dengan rencana, dengan menggunakan aplikasi google classroom dan whatsapp sebagai media pembelajaran. Efektivitas model pembelajaran tersebut terhadap penalaran statistis adalah terbukti efektif, dimana rata-rata nilai penalaran statistis sebesar 74,58 dan peningkatan penalaran pada kategori sedang sebesar 54\%.
\end{abstract}

\section{Kata Kunci: E-Learning, E-Learning Ketika Covid-19, Modul Berbasis Masalah, PACE, Penalaran Statistis.}

\begin{abstract}
The Covid-19 pandemic condition prompted the government to recommend study from home, therefore e-learning was used as an alternative implementation of learning. In e-learning it is necessary to set learning objectives, learning models and learning media that are used to deliver teaching materials. Therefore, PACE model using problem-based learning with modules aid is used with the aim of learning statistical reasoning. The purpose of this study was to determine the implementation of e-learning with the PACE model assisted by problem-based modules in statistical lectures in the Covid-19 pandemic condition and the effectiveness of e-learning with the PACE model assisted by problem-based modules in statistical lectures on statistical reasoning. The research method used is a descriptive method with a sample of 24 students who took the research statistics course. The results showed that the implementation of e-learning with PACE model using problem-based learning with modules aid in statistics lectures in the Covid-19 pandemic conditions can be carried out according to the plan, using the google classroom application and whatsapp as learning media. The effectiveness of the learning model on statistical reasoning is proven effective, where the average value of statistical reasoning is 74.58 and the reasoning increase in the medium category is $54 \%$.
\end{abstract}

Keywords: E-Learning, E-Learning During Covid-19, Problem Based Module, PACE, Statistical Reasoning.

\section{A. Pendahuluan}

Kondisi dimana Covid - 19 dinyatakan sebagai darurat global pada 30 Januari 2020 dan pandemic global pada 12 Maret 2020 (WHO) sangat berpengaruh terhadap sekolah, guru dan siswa. Di Indonesia, pemerintah telah membatasi mobilisasi masyarakat dalam upaya mencegah penyebaran penyakit, dan terus memberikan anjuran untuk bekerja dari rumah, 
belajar dari rumah dan beribadah di rumah. Sekolah dan perguruan tinggi ditutup sementara sejak 14 Maret 2020. Hal ini tentu saja berdampak yang signifikan terhadap proses pembelajaran. Pembelajaran biasanya dilaksanakan di kelas dimana guru dan siswa bertatap muka, berubah menjadi pembelajaran virtual yang memanfaatkan teknologi informasi dan komunikasi. Oleh karena itu, pembelajaran elektronik (e-learning) dianggap sebagai pendekatan terbaik untuk melanjutkan proses belajar mengajar selama pandemic.

Pembelajaran e-learning telah dilakukan pada perkuliahan statistika di perguruan tinggi (Tudor, 2006; Blackburn, 2015; Yang 2017). Mata kuliah statistika merupakan mata kuliah yang wajib ditempuh sebagai syarat untuk menyelesaikan perkuliahan pada berbagai bidang studi (Garfield dan Ben-Zvi, 2005). Hal ini terjadi karena mata kuliah statistika mendukung mereka dalam mengembangkan keterampilan penelitian. Rumsey (2002) menyatakan bahwa tujuan dari pembelajaran statistika adalah peserta didik mengerti statistika dengan baik agar dapat mendapat informasi dari data yang ada, mengkritik dan membuat keputusan berdasarkan informasi tersebut serta bertujuan untuk mengembangkan keterampilan penelitian. Oleh karena itu, tujuan pembelajaran statistika saat ini lebih menekankan pada pemahaman konsep dan penalaran statistis dari pada pemahaman prosedural (Jin, Kim, McGhee, dan Reiser, 2011; Türegün, 2014; Idris dan Yang, 2015; Chan, Ismail, dan Sumintono, 2016; Kalobo, 2016). Dengan pemahaman konsep dan penalaran statistis yang mumpuni, akan membuat siswa mengerti statistika dengan baik.

Penalaran statistis didefinisikan sebagai cara bernalar dengan ide-ide statistic dan memahami informasi statistis (Garfield dan Gal,1997). Lovett (2001) menginterpretasikan penalaran statistis sebagai cara menggunakan alat statistik dan konsep untuk membuat rangkuman, prediksi, dan menarik kesimpulan dari data. Sementara del Mas (2002) mengemukakan bahwa penalaran statistis merupakan kemampuan menjelaskan mengapa dan bagaimana suatu hasil di produksi serta mengapa dan bagaimana menarik kesimpulan. Secara terperinci tahap demi tahap dalam penalaran statistis, Chan \& Ismail (2014) menyatakan ada empat konstruksi kunci penilaian penalaran statistis berdasarkan kerangka Jones et al yaitu: 1) describing data; (2) organizing and reducing data; 3) representing data; 4) analyzing and interpreting data.

Pada pembelajaran e-learning untuk mendukung belajar dan interaksi yang bermakna, ada tiga komponen kunci, yaitu: 1) model atau konstruks pedagogic, 2) strategi belajar dan pembelajaran, dan 3) teknologi belajar (Dabbagh \& Bannan-Ritland, 2005). Selanjutnya Clark dan Mayer (2003) menyebutkan bahwa dalam pembelajaran e-learning ini mencakup empat hal penting, yaitu 1) isi yang disajikan memiliki relevansi dengan tujuan khusus pem-belajaran yang ingin dicapai, 2) menggunakan metode-metode pembelajaran melalui contoh-contoh dan latihan-latihan untuk membantu belajar peserta didik, 3) menggunakan media seperti gambargambar dan kata-kata untuk menyajikan isi dan metode, dan 4) mengembangkan dan membangun pengetahuan dan keterampilan baru sesuai dengan tujuan individu dan peningkatan organisasi. Dimana pada lingkungan e-learning, guru lebih banyak bertanggung jawab dalam membuat rancangan (Heinich, Molenda, Russell, dan Smaldino, 1999). Berdasarkan urraian tersebut, maka diperlukan sebuah model pembelajaran yang sesuai.

Model pembelajaran PACE merupakan salah satu model pembelajaran yang dapat digunakan pada pembelajaran statistika. PACE dikembangkan oleh Lee, adapun PACE merupakan singkatan dari Project, Activity, Cooperative and Exercise. Prinsip utama pada pembelajaran PACE ini adalah mengkonstruksi pengetahuan melalui proses bimbingan, latihan dan umpan balik untuk mempertahankan pengetahuan baru, serta melakukan diskusi untuk memecahkan masalah (Lee, 1998). Pada pembelajaran PACE ini, proyek merupakan komponen penting. Dimana proyek dikerjakan secara berkelompok dengan mengacu pada petunjuk yang diberikan oleh guru (Lee,1998). Pearce dan Cline (2006) menyatakan bahwa pembelajaran PACE efektif untuk membantu mahasiswa sarjana memahami dan menerapkan 
pengetahuan dan keterampilan statistik mereka. Namun,hasil penelitian yang dilakukan oleh Dasari (2009) menunjukkan bahwa pembelajaran PACE efektif untuk mahasiswa dengan kemampuan tinggi.

Pada tempat kerja peneliti, kemampuan mahasiswanya tergolong sedang dan kurang. Sedikit sekali mahasiswa dengan kemampuan tinggi. Oleh karena itu, pembelajaran PACE yang akan diterapkan pada perkuliahan statistika dimodifikasi terlebih dahulu dengan berbantuan modul berbasis masalah. Depdiknas (2008) mendefinisikan modul sebagai alat atau sarana pembelajaran yang berisi materi, metode, batasan-batasan, dan mengevaluasi secara sistematis dan menarik untuk mencapai kompetensi yang diharapkan sesuai dengan kompleksitasnya. Smith dan Harlan (2009) menyatakan bahwa memberikan masalah kehidupa nyata yang kompleks dapat mendorong siswa untuk mengkonstruksi pengetahuannya. Proses konstruksi pengetahuan yang terjadi akan membuat siswa mahir dalam mengumpulkan dan menerapkan pengetahuan dalam menyelesaikan suatu permasalahan. Blackburn (2015) juga menyatakan bahwa pemberian masalah akan membuat siswa untuk menerapkan teori dan mencari informasi tambahan di luar yang disediakan sehingga membuat siswa berpikir kritis serta mengembangkan kemampuan analitisnya. Pada modul berbasis masalah yang peneliti susun, disajikan tujuan pembelajaran kemudian materi, setelah materi kemudian disajikan masalah, latihan dan evaluasi. Dalam menyelesaikan masalah yang diberikan, peneliti memberikan kegiatan aktivitas yang menuntun siswa dalam menyelesaikan permasalahan. Tujuannya adalah membiasakan siswa untuk bernalar dan memahami konsep dengan baik.

Pada masa pandemic ini, secara umum guru hanya mentransfer pengetahuan melalui elearning. Mereka tidak menyiapkan bahan ajar atau strategi pembelajaran khusus. Pada umumnya guru di Indonesia hanya menginformasikan beberapa referensi yang dapat digunakan pada pembelajaran, mereka tidak menyiapkan bahan ajar yang khusus (modul). Sedangkan strategi pembelajarannya mereka menggunakan pembelajaran konvensional yang dilakukan secara virtual. Pembelajaran konvensional yang dilakukan di Indonesia yaitu guru memberikan penjelasan, contoh soal kemudian memberikan latihan pada akhir pembelajaran. Padahal kondisi peserta didik yang dihadapi oleh setiap guru adalah berbeda. Oleh karena itu, peneliti tertarik untuk meneliti implementasi dari e-learning dengan model PACE berbantuan modul berbasis masalah pada perkuliahan statistika sebagai salah satu solusi yang dapat digunakan pada kondisi pandemi Covid-19 ini. Adapun tujuan dari penelitian ini adalah mengetahui bagaimana pelaksanaan e-learning dengan model PACE berbantuan modul berbasis masalah pada perkuliahan statistika dalam kondisi pandemic Covid-19 serta efectivitas dari dari elearning dengan model PACE berbantuan modul berbasis masalah pada perkuliahan statistika terhadap penalaran statistis.

\section{B. Metodologi Penelitian}

Desain penelitian yang digunakan pada penelitian ini adalah deskriptif. Penelitian deskriptif adalah suatu metode penelitian yang ditujukan untuk menggambarkan fenomenafenomena yang ada, yang berlangsung saat ini (Sukestiyarno, 2020). Selain mendiskripsikan proses pembelajaran e-learning dengan model PACE berbatuan modul berbasis masalah, pada penelitian ini juga akan diungkapkan hambatan dan tantangan apa saja yang ditemui peneliti dalam mengimplementasikannya serta bagaimana efektifitas dari pembelajaran tersebut terhadap penalaran statistis.

Penelitian dilakukan di tempat peneliti bekerja yaitu STKIP Sebelas April. Adapun pemilihan sampel dilakukan dengan cara purposive sampling. Sampel penelitian adalah mahasiswa semester 6 program studi pendidikan matematika yang mengambil matakuliah statistika penelitian. Mahasiswa tersebut berjumlah 24 orang yang terdiri dari 5 orang laki-laki dan 19 orang perempuan. Dimana mahasiswa tersebut berasal dari berbagai kota/ kabupaten yang ada di Jawabarat dan Banten, yaitu Kabupaten Sumedang, Kabupaten Majalengka, 
Kabupaten Purwakarta, Kabupaten Subang, Kabupaten Pandeglang, Kabupaten Bandung,dan Kabupaten Karawang. Mayoritas pekerjaan orang tua adalah petani dan buruh.

Instrumen yang digunakan pada penelitian ini adalah, Rencana Pembelajaran Satu Semester (RPS), modul berbasis masalah dan soal tes. Dimana semua instrument yang digunakan telah divalidasi oleh lima orang validator ahli. Saran perbaikan yang diberikan oleh validator ahli menjadi acuan peneliti dalam memperbaiki instrument. Soal tes, setelah divalidasi oleh ahli kemudian dilakukan uji coba kepada siswa. Soal yang tidak valid dan reliable dihilangkan dari soal tes.

Hasil penelitian diperoleh berupa data kuantitatif yang dianalisis secara deskripsi dan data nilai tes penalaran siswa yang dianalisis secara statistic. Dimana data tersebut akan dihitung nilai indeks gainnya untuk mengetahui besarnya peningkatan penalaran statistis mahasiswa, serta dilakukan juga uji t satu sampel untuk mengetahui pengaruh dari implementasi pembelajaran e - learning dengan model PACE berbatuan modul berbasis masalah.

\section{Hasil Penelitian dan Pembahasan}

Pelaksanaan pembelajaran e-learning dengan model PACE berbatuan modul berbasis masalah pada penelitian ini dideskripsikan sebagai berikut:

\section{Persiapan pembelajaran}

Pembelajaran dilakukan secara online dengan menggunakan google classroom dan whatsApp. Terlebih dahulu peneliti membuat grup whatsApp untuk meberikan informasi tentang pembelajaran. Setelah itu, peneliti membuat kelas pada google classroom. Kode kelas peneliti bagikan melalui whatsApp grup, sehingga semua siswa bisa bergabung pada kelas tersebut. Tampilan kelas dapat dilihat pada gambar 1.

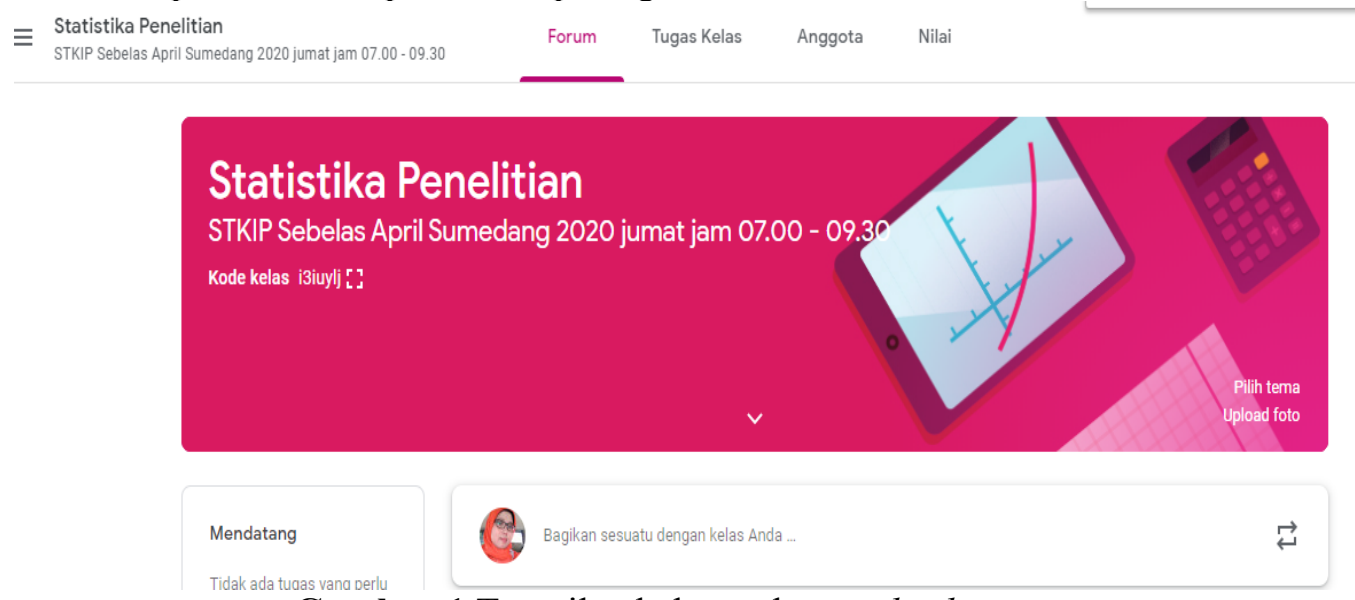

Gambar 1 Tampilan kelas pada google classroom.

Selain persiapan media untuk menyampaikan pembelajaran, tentu saja dilakukan juga persiapan perangkat pembelajaran, materi pembelajaran serta instrument tes. Peneliti menyusun Rencana Pembelajaran Semester (RPS), materi yang disajikan melalui modul berbasis masalah, bahan proyek, tugas, serta soal tes penalaran statistis. Semua perangkat pembelajaran dan instrument penelitian terlebih dahulu divalidasi oleh lima orang ahli. Untuk instrument soal tes penalaran statistis, selain divalidasi oleh ahli juga dilakukan uji validitas empiris. Model pembelajaran yang diterapkan pada e-learning ini adalah model pembelajaran PACE, sehingga unsure proyek, aktivitas, cooperative dan exercise (latihan) harus tercermin pada pembelajaran yang dirancang. Unsur proyek akan diberikan berupa bahan proyek yang diberikan setelah pembelajaran diberikan, dimana hasilnya berupa laporan yang dikumpulkan pada pertemuan berikutnya. Unsur aktivitas terdapat pada modul berbasis masalah, dimana aktivitas disajikan berupa langkah-langkah yang diberikan oleh peneliti sebagai panduan dalam menyelesaikan 
masalah yang diberikan pada modul. Unsur aktivitas pada modul berbasis masalah dapat dilihat pada gambar 2 .

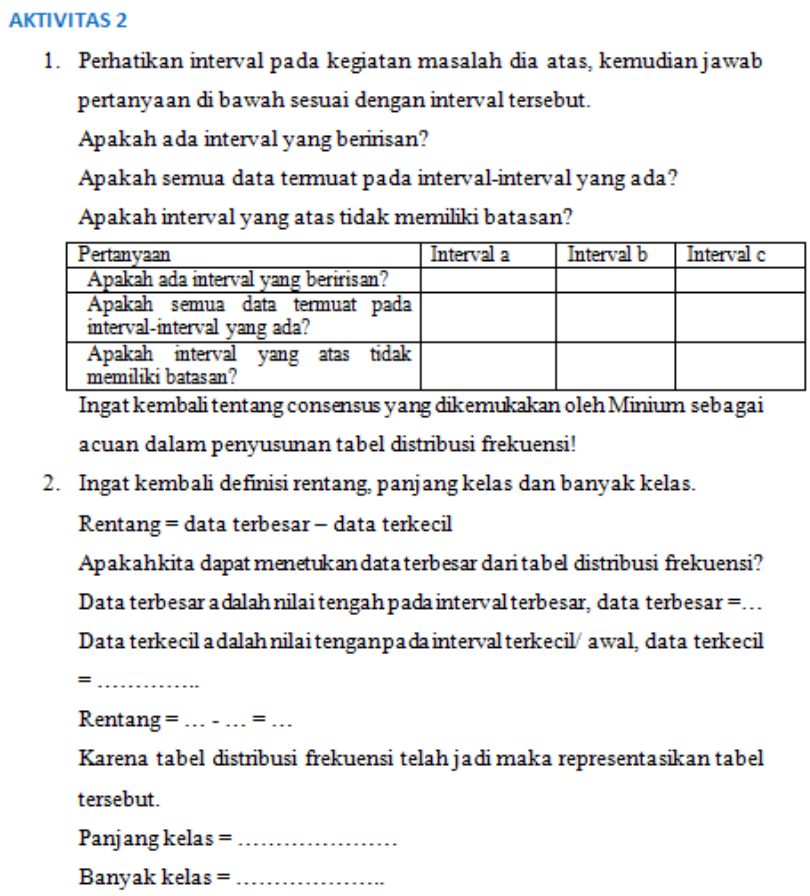

Gambar 2 Aktivitas yang terdapat pada modul berbasis masalah

Unsur kooperatif atau pembelajaran kooperatif, dilakukan melalui proyek yang diberikan. Dimana pada setiap laporan mahasiswa diminta untuk melampirkan hasil diskusi dari kelompok kecil yang terdiri dari 4 orang mahasiswa dengan kemampuan yang berbeda. Diskusi juga dilakukan pada grup whatsApp kelas. Pada modul juga terdapat latihan soal beserta kunci jawabannya sehingga mahasiswa dapat mengukur kemampuannya dalam materi yang disajikan.

\section{Pelaksanaan pembelajaran}

Pada pertemuan pertaman peneliti melaksanakan tes awal secara tatap muka di kelas sambil menginformasikan pembelajaran yang akan dilakukan menggunakan modul, tes awal dilaksanakan sebelum diberlakukan Study From Home (SFH). Tes awal dilakukan untuk mengetahui kemampuan awal penalaran statistis mahasiswa pada materi statistika deskriptif. Pertemuan 2 sampai pertemuan 8 pembelajaran dilaksanakan secara daring menggunakan google classroom dan whatsapp. Adapun tampilan pembelajaran pada google classroom dapat dilihat pada gambar 3 . 


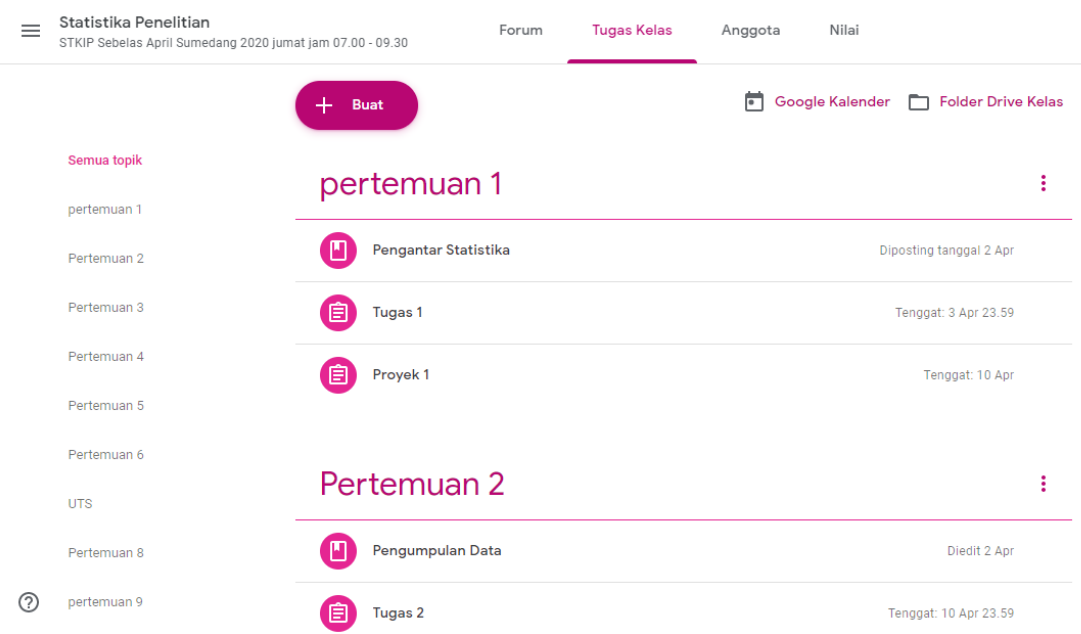

Gambar 3 Tampilan materi, tugas dan proyek pada google classroom

Dosen memposting materi, tugas dan proyek sebelum pertemuan dilaksanakan. Materi diberikan dalam bentuk modul berbasis masalah. Dimana modul tersebut memuat tujuan pembelajaran, materi, contoh soal, masalah, aktivitas, rangkuman, latihan soal, tes formatif, kunci jawaban serta pedoman penilaian. Tugas yang diberikan pada mahasiswa merupakan masalah dan aktivitas yang terdapat pada modul. Masalah yang diberikan berupa soal penalaran statistis. Kegiatan aktivitas merupakan langkah-langkah yang merupakan petunjuk dalam menyelesaikan masalah, sehingga mahasiswa terbiasa dengan soal-soal penalaran statistis. Tugas dikerjakan secara individu dan dikumpulkan pada hari pembelajaran dilaksanakan. Tugas tersebut kemudian diperiksa, dikomentari dan dikembalikan kepada mahasiswa. Materi yang dipelajari beserta tugas yang harus dikerjakan merupakan unsur Aktivitas dari model pembelajaran PACE. Seperti yang diurailan di atasa bahwa pada modul terdapat juga latihan soal, tes formatif dan kunci jawaban terdapat pada modul berbasis masalah. Sehingga unsur exercise/ latihan pada model PACE sudah termuat juga pada modul. Hasil pengumpulan tugas pada google classroom dapat dilihat pada gambar

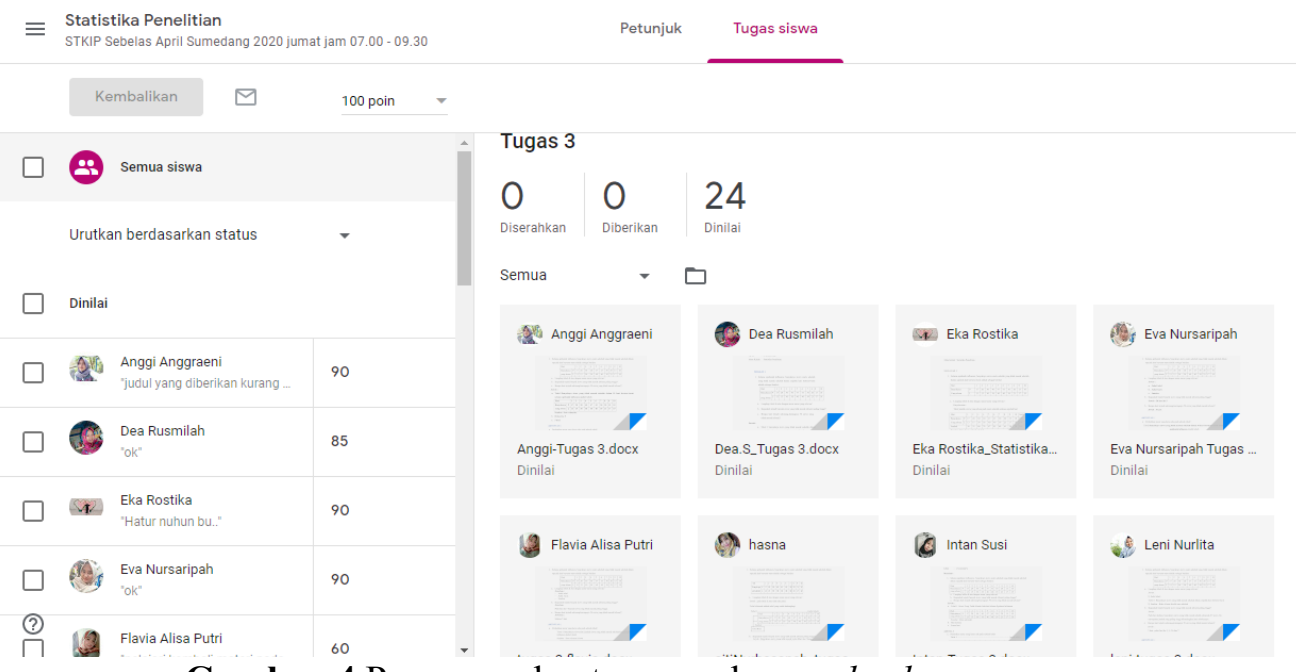

Gambar 4 Pengumpulan tugas pada google classroom

Pada pembelajaran PACE ini, proyek merupakan unsur yang penting. Proyek diberikan bersamaan dengan materi dan tugas, tetapi pengumpulannya dilakukan pada pertemuan berikutnya. Proyek dikerjakan secara berkelompok, karena pembelajaran dilakukan pada kondisi pandemic covid-19 diskusi dilakukan melalui whatsapp grup kelompok belajar yang 
telah dibuat oleh peneliti. Satu kelompok terdiri dari 4 orang mahasiswa dengan kemampuan yang heterogen. Harapannya dengan kelompok yang heterogen, nantinya diperoleh kesamaan persepsi mengenai suatu konsep. Hail dari proyek ini berupa laporan beserta video yang mempresentasikan hasil diskusi kelompok. Laporan secara tertulis dikumpulkan melalui google classroom, sedangkan video presentasi dikirim melalui email. Selanjutnya laporan proyek baik berupa tulisan maupun video diperiksa oleh dosen pengajar untuk kemudian dilakukan penguatan konsep. Pada laporan dilampirkan diskusi yang dilaksanakan oleh kelompok melalui whatsapp grup. Pada gambar 3 dapat dilihat contoh diskusi kelompok dalam menyelesaikan proyek.

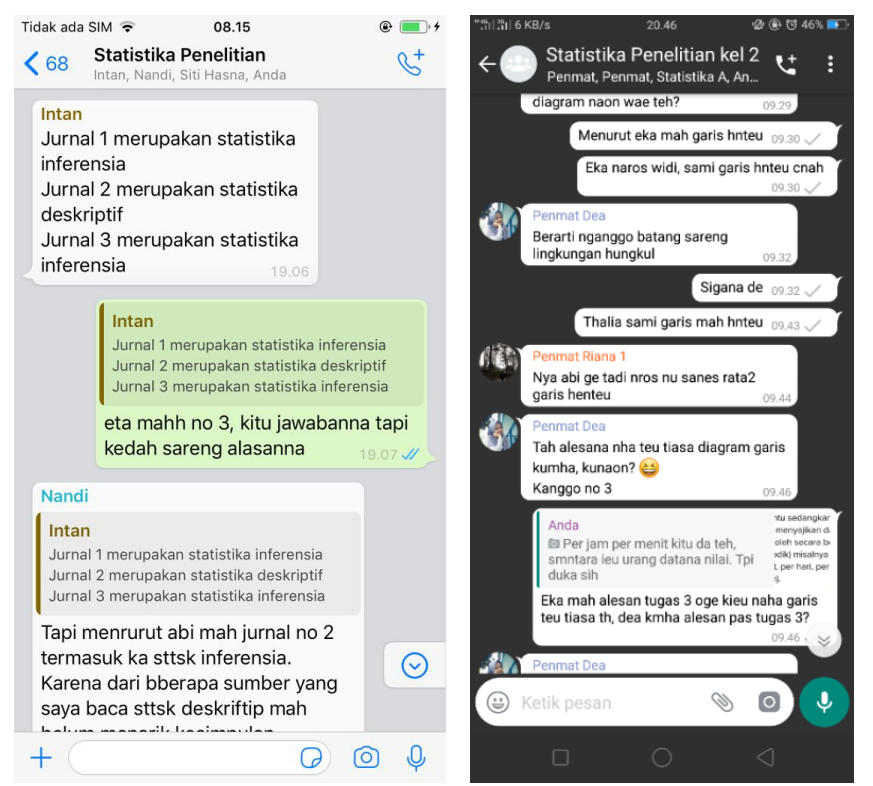

Gambar 5 Diskusi kelompok dalam mengerjakan proyek

Pada kegiatan proyek ini, selain merupakan unsur proyek, terdapat juga unsur pembelajaraan kooperatif. Dimana mahasiswa melakukan diskusi dalam menyelesaikan proyek yang diberikan. Pada gambar 4 terdapat chat

"eka naros widi, sami garis henteu cenah" (Eka bertanya sama Widi, sama diagram garis tidak bisa)

"Thalia sami garis mah henteu” (Thalia juga sama diagram garis tidak)

Dari kalimat tersebut berarti, diskusi dilakukan juga dengan anggota kelompok lain. Dimana hasil diskusi dengan kelompok lain tersebut didiskusikan kembali dengan anggota kelompoknya untuk memperoleh pemahaman yang sama. Jika mahasiswa masih tidak mengerti dengan materi, tugas maupun proyek yang diberikan mahasiswa biasanya bertaya melalui whatsapp baik secara pribadi maupun pada grup kepada dosen pengajar. Mahasiswa belum terbiasa untuk menggunakan fasilitas komentar yang terdapat pada google classroom sehingga lebih nyaman bagi mereka untuk menggunakan whatsapp untuk diskusi atau bertanya kepada pengajar. Pada pengerjaan proyek, terdapat juga penggunaan software seperti Ms. Excel dan SPSS. Oleh karena itu, pada materi dosen menyertakan juga link Youtube sebagai tutorial mereka dalam menggunakan software tersebut untuk materi statistika.

Pertemuan ke delapan merupakan pertemuan dengan rencana UTS. Pada pelaksanaan UTS, dosen telah menyiapkan soal beserta google form yang harus diisi sebagai absensi kehadiran UTS pada google classrrom. Dosen memberikan petunjuk pengerjaan UTS dan mengingatkan kepada mahasiswa untuk bersikap jujur dalam mengerjakan soal UTS. Bagi mahasiswa yang melakukan kecurangan, dosen pengajar tidak akan memberikan toleransi. Selain itu, jika pada tugas maupun proyek waktu pengerjaannya lebih leluasa, pada UTS, waktu 
pengerjaan dibatasi oleh peneliti sesuai dengan aturan yaitu untuk mata kuliah dengan 3 SKS maka waktu ujiannya sebanyak 100 menit. Ujian bersifat open sheet, dimana mahasiswa diijinkan untuk melihat catatan yang telah dibuat sebelumnya pada selembar kertas A4. Catatan tersebut dilampirkan beserta jawaban dan coretan (kotretan) yang mereka lakukan dalam mengerjakan UTS.

\section{Evaluasi pembelajaran}

Pada setiap pertemuan, peneliti selalu menanyakan kepada mahasiwa mengenai pelaksanaan pembelajaran e-learning yang dilakukan. Pada umumnya mereka hanya mengeluhkan perihal sinyal atau jaringan internet yang kadang kurang bagus. Ketika waktu pengerjaan dibatasi, beberapa dari mereka diminta untuk membantu mengerjakan tugas adiknya. Pengiriman tugas pada google classroom dengan bentuk file Ms. Word, kadang isinya hilang tidak bisa terbaca oleh dosen, sehingga dosen meminta dikirim ulang. setiap minggunya dosen mengecek siapa saja yang belum mengumpulkan tugas dan mengingatkannya di grup whatsapp untuk segera mengirim tugas. Setiap tugas yang dikerjakan oleh mahasiswa, diperiksa oleh dosen pengajar. Apabila jawaban dari mahasiswa, penguasaannya masih kurang, dosen meminta untuk mempelajari kembali materi yang ada pada modul dan mengirim kembali jawaban yang telah diperbaiki dengan konsekuensi masa pengumpulan tugasnya menjadi terlambat pada google classroom.

Penerapan Model PACE pada kondisi pandemic corona, tidak mengalami hambatan yang berarti. Setiap komponen pada model pembelajaran PACE dapat diterapkan. Walaupun pada mulanya mahasiswa kebingungan ketika mereka harus mengerjakan proyek dan membuat video untuk mepresentasikan hasil diskusi mereka. Modul berbasis masalah sangat membantu dalam pelaksanaannya model PACE ini.

Evaluasi juga dilakukan terhadap modul berbasis masalah yang digunakan. Pada pertemuan pertama, mahasiswa masih bingung dengan aktivitas yang merupakan petunjuk dalam menyelesaikan masalah yang diberikan. Mereka mengira, antara masalah dan aktivitas merupakan suatu hal yang berbeda. Sehingga peneliti menyempurnakan kembali modul berbasis masalah sehingga lebih mudah dipahami oleh mahasiswa pada setiap pertemuannya.

Evaluasi juga dilakukan terhadap penalaran statistis mahasiswa. Pada tabel 1. dapat dilihat statistika deskriptif dari tes akhir penalaran statistis.

Tabel 1. Statistics

Nilai

$\mathbf{N}$

Valid

Missing

Mean

Std. Deviation

Kurtosis

Std. Error of Kurtosis

Berdasarkan tabel 1, dapat dilihat bahwa nilai maksimum dari tes akhir adalah 100, nilai minimum 40 dengan rata-rata 74,58 dan simpangan baku 17,565. Pada tabel 2 . dan tabel 3 dapat dilihat hasil analisis statistik dari pembelajaran e-learning dengan model PACE berbantuan modul berbasis masalah terhadap penalaran statistis. 
Tabel 2 Tests of Normality

\begin{tabular}{lccccccr}
\hline & \multicolumn{4}{c}{ Kolmogorov-Smirnov $^{\text {a }}$} & \multicolumn{3}{c}{ Shapiro-Wilk } \\
\hline & Statistic & df & \multicolumn{1}{c}{ Sig. } & Statistic & df & \multicolumn{1}{c}{ Sig. } \\
\hline Nilai & .134 & 24 & $.200^{*}$ & .938 & 24 & .147 \\
\hline
\end{tabular}

Berdasarkan hasil uji normalitas pada tabel 2. dengan menggunakan program SPSS, terlihat bahwa sig. dari data yaitu $0,2,(>0,05)$ sehingga $\mathrm{H} 0$ diterima. Artinya variabel nilai tes penalaran statistis mahasiswa berdistribusi normal. Untuk melihat homogenitas data, perhatikan nilai kurtosis pada tabel 1 . yaitu $-0,724$. Nilai tersebut sangat kecil yang berarti mendekati nol, yang berarti datanya bersifat homogen.

Tabel 3. One-Sample Test

$$
\text { Test Value }=65
$$

\begin{tabular}{|c|c|c|c|c|c|}
\hline \multirow[b]{2}{*}{$\mathrm{t}$} & \multirow[b]{2}{*}{ df } & \multirow[b]{2}{*}{ Sig. (2-tailed) } & \multirow{2}{*}{$\begin{array}{c}\text { Mean } \\
\text { Difference }\end{array}$} & \multicolumn{2}{|c|}{$\begin{array}{c}95 \% \text { Confidence Interval of } \\
\text { the Difference }\end{array}$} \\
\hline & & & & Lower & Upper \\
\hline 2.673 & & .014 & 9.583 & 2.17 & 17.0 \\
\hline
\end{tabular}

Berdasarkan hasil uji normalitas pada tabel 3. dengan menggunakan program SPSS, terlihat bahwa sig. dari data yaitu $0,014,(<0,05)$ sehingga $\mathrm{H} 0$ ditolak. Jadi rataan sampel tidak sama dengan 65. Dari tabel di atas dapat dilihat baha rataan dari data adalah 74,58 ternyata lebih besar dari 65. Selain itu, dilakukan juga perhitungan indeks gain untuk mengetahui peningkatan dari penalaran statistis mahasiswa. Adapun hasilnya dapat dilihat pada tabel 4.

Tabel 4. Peningkatan Penalaran Statistis

\begin{tabular}{cc}
\hline Kategori & Jumlah \\
\hline Tinggi & 7 \\
Sedang & 13 \\
Rendah & 4 \\
\hline
\end{tabular}

\section{Pembahasan}

Pembelajaran e-learning pada matakuliah statistika bukanlah hal yang baru. Beberapa penelitian telah melakukannya yaitu Tudor (2006) dengan hasil bahwa siswa merasa puas dengan pembelajaran online dengan kunci pengorganisasian dan keterlibatan pada pembelajaran tersebut. Oleh karena hal tersebut, peneliti menggunakan aplikasi google classroom, Whatsapp, google form dan email dalam melaksanakan pembelajaran e-learning dengan model PACE berbantuan modul berbasis masalah sebagai media untuk mengorganisasikan dan mengecek keterlibatan setiap pihak dalam pembelajaran. Selain itu, setiap aplikasi tersebut tersebut merupakan aplikasi yang sudah dikenal oleh mahasiswa, sehingga mahasiswa tidak lagi harus mempelajari tentang cara menggunakan aplikasi tersebut. Dalam kondisi wabah covid-19 ini, pertimbangan penggunaan kuota juga menjadi salah satu pertimbangan peneliti dalam memilih aplikasi tersebut. Yaniawati (2020) dan Azhar (2020) menyatakan bahwa google classroom dan whatsapp group merupakan aplikasi yang penggunaannya mudah dan hemat kuota sehingga dapat digunakan sebagai media pembelajaran online.

Model pembelajaran diperlukan pada pembelajaran online atau e-learning. Pemilihan model PACE tentu saja berdasarkan pada pertimbangan tujuan pembelajaran statistika yaitu penalaran statistis. E-learning dengan model PACE berbantuan modul berbasis masalah dalam pelaksanaan perkuliahan statistika penelitian sangat efektif digunakan. Pembelajaran dapat 
terlaksana sesuai dengan yang direncanakan. Peran dosen pada pembelajaran adalah sebagai fasilitator, dosen menyediakan bahan ajar, tugas, mengingatkan mahasiswa dan juga melaksanakan evaluasi. Komunikasi pada pembelajaran pun lebih aktif dibandingkan dengan pembelajaran di kelas. Beberapa mahasiswa yang biasanya malu untuk bertanya ketika pembelajaran di kelas, pada pembelajaran e-learning dengan model PACE berbantuan modul berbasis masalah lebih aktif bertanya. Hal ini karena media komunikasi pada google classroom yang dapat memberikan komentar secara pribadi serta mahasiswa juga dapat memberikan komentar secara pribadi melalui whatsapp. Sesuai dengan hasil penelitian yang dilakukan oleh Kusumah dan Hamidah (2020), Munawaroh (2019), Sutame (2019), bahwa whatsapp efektif sebagai media komunikasi pada pembelajaran matematika. Selain itu, jika dengan pembelajaran di kelas biasanya dosen kesulitan dalam mengorganisasi tugas. Dengan penggunaan e-learning hal tersebut tidak terjadi lagi. Sesuai dengan pendapat Iftakhar (2016) bahwa google classroom dapat membantu guru dalam mengorganisasikan kelas serta memonitoring peserta didik untuk belajar dan tentu saja google classroom juga mudah digunakan, menghemat waktu, fleksibel, gratis dan mudah diakses. Penggunaan modul berbasis masalah tentu saja membuat mahasiswa lebih mudah memahami materi yang diberikan. Hal ini karena pada modul biasanya memiliki suatu rangkaian kegiatan yang terkoordinir dengan baik berkaitan dengan materi dan media serta evaluasi (Lasmiyati dan Harta, 2014).

Adapun kendala yang terjadi lebih disebabkan oleh koneksi internet yang tidak sama pada setiap daerah, terlebih dalam kondisi pandemic Covid-19 dimana banyak orang yang menggunakan koneksi internet baik untuk belajar maupun untuk bekerja. Hal ini sesuai dengan pendapat guru-guru yang diutarakan pada penelitian Mailizar, Almanthari, Maulina dan Bruce (2020). Hambatan yang terjadi selain pada koneksi internet, juga terhadap penggunaan modul. Pada tugas pertama yang terdapat pada modul 1, beberapa mahasiswa salah mengerjakan tugas. Mereka tidak membaca petunjuk yang terdapat pada modul, sehingga pada tugas tersebut dosen mengembalikan tugas mereka dan meminta mahasiswa tersebut untuk mempelajari dan memahami kembali modul tersbut. Hal ini terjadi karena mahasiswa baru pertama kali menggunakan modul dalam pembelajaran. Biasanya mereka mendengarkan langsung petunjuk atau penjelasan dari dosen. Hal ini juga terjadi pada penelitian Lasmiyati dan Harta (2014) yaitu pada awal pembelajaran menggunakan modul, beberapa siswa tidak membaca perintah atau aturan yang terdapat di awal modul, sehingga masih bertanya kepada guru akan melakukan kegiatan apa. Proses adaptasi diperlukan dalam peralihan kondisi pembelajaran dari pembelajaran di kelas menjadi pembelajaran online (e-learning).

Berdasarkan hasil analisis statistik yang dilakukan, e-learning dengan model PACE berbantuan modul berbasis masalah efektif dalam meningkatkan penalaran statistis. Hal ini dilihat bahwa nilai tes akhir mahasiswa lebih dari 65 yang merupakan nilai ketuntasan minimal. Selain itu, peningkatan penalaran statistis pun pada kategori tinggi sebanyak 7 orang, sedang 13 orang dan rendah 4 orang. Hal ini tentu saja terjadi karena pembelajaran PACE memfasilitasi mahasiswa untuk mengembangkan penalaran, untuk mengeksplorasi dan menyelesaikan masalah, untuk mengkomunikasikan ide mereka dengan rekannya, untuk mengadopsi prosedur penyelesaian, dan memberikan kesempatan yang banyak untuk belajar proses satistika (Lee, 1998). Selain itu, modul berbasis masalah pun membuat mahasiswa lebih matang dalam melakukan pembelajaran. Dimana proses pembelajarn dikendalikan oleh mereka sendiri, sehingga siswa yang merasa belum menguasai materi dapat mengulangnya kembali. Hal ini sesuai dengan hasil penelitian Yusuf, Jaenudin dan Tita (2016) bahwa belajar dengan modul proses belajarnya dapat disesuaikan dengan kemampuan belajar mahasiswa itu sendiri, maksudnya proses belajar dikendalikan oleh mahasiswa. Terlebih dimana modul yang digunakan merupakan modul berbasis masalah, sehingga lebih mempersiapkan mahasiswa dalam menghadapi permasalahan-permasalahan yang kontekstual sehingga mereka terlatih. Seperti yang dinyatakan oleh Smith dan Harlan (2009) masalah mendorong konstruksi 
pengetahuan dengan memulai setiap pengalaman belajar dengan masalah kehidupan nyata yang kompleks. Proses konstruksi pengetahuan yang terjadi pada pembelajaran berbasis masalah akan membuat siswa mahir dalam mengumpulkan dan menerapkan pengetahuan dalam menyelesaikan suatu permasalahan. Sehingga dengan demikian, siswa akan mampu untuk melakukan penalaran. Pembelajaran yang dirancang sesuai dengan kebutuhan peserta didik, tentu saja akan memberikan hasil yang optimal.

\section{E. Kesimpulan}

Pelaksanaan e-learning dengan model PACE berbantuan modul berbasis masalah pada perkuliahan statistika dalam masa pandemic Covid-19 dapat berjalan dengan baik sesuai dengan rencana dengan menggunakan aplikasi google classroom dan whatsapp sebagai media. Tujuan pembelajaran dapat tercapai dengan baik sesuai dengan target yang telah ditentukan. Elearning dengan model PACE berbantuan modul berbasis masalah efektif terhadap penalaran statistis. Dimana rata-rata nilai tes akhir penalaran mahasiswa yaitu 74,58 , lebih dari nilai ketuntasan minimal (65). Peningkatan penalaran statistis 4 orang pada kategori rendah, 13 orang pada kategori sedang dan 7 orang pada kategori tinggi. Berdasarkan dari hasil penelitian, elearning model PACE berbantuan modul berbasis masalah dapat dijadikan sebagai alternatif pembelajaran statistika pada kondisi pandemic covid-19.

\section{DAFTAR PUSTAKA}

Azhar, A. P. (2020). Efektivitas Penggunaan Media Pembelajaran online dalam sebaran covid 19. Seminar Nasional Online Pengabdian Masyarakat. Jakarta, LP3I Politeknik.

Blackburn, G. (2015). Effectiveness of eLearning in statistics: Pictures and stories. E-Learning and Digital Media, 12(5-6), 459-480.

Chan, S. W. dan Ismail, Z. (2014). Developing Statistical Reasoning assessment Instrument for High School Students in Descriptive Statistics.5th World Conference on Educational Sciences - WCES 2013. Procedia - Social and Behavioral Sciences 116. 4338 - 4344.

Chan, S. W., Ismail, Z., dan Sumintono, B. (2016). Assessing Statistical Reasoning In Descriptive Statistics: A Qualitative Meta-Analysis. Jurnal Teknologi (Sciences \& Engineering),v.78,n.6-5,p.29-35.

Clark, R.C., \& Mayer, R. E. (2003). E-Learning and the Science of Instruction. Market Street, San Fransisco, CA: John Wiley \& Sons, Inc.

Dabbagh, N. \& Bannan-Ritland, B. (2005). Online Learning. Concept, Strtagies, and Application. Upper Saddle Rive, NJ: Pearson Education, Inc.

Dasari, D. 2009. Peningkatan Kemampuan Penalaran Statistis Mahasiswa melalui-Model PACE. Disertasi. PPS UPI Bandung: Tidak diterbitkan.

delMas, R. (2002). Statistical Literacy, Reasoning, and Leraning: A Commentary". Journal of Statistics Education, 10(3). Diambil dari: www.amsat.org/publicatins/jse/v103/delmas_disscussion.html. 
Depdiknas.(2008). Pengembangan Bahan Ajar. Sosialisasi KTSP 2008.

Garfield, J., dan Ben-Zvi, D. (2005). How students learn statistics revisited: A current review of research on teaching and learning statistics. International Statistical Review, 75(3), 371-396.

Garfield,J.B. dan Gal. (1997). Teaching and Assesing Statistical Reasoning. NCTM.

Henich, R., Molenda, M., Russell, J.D., \& Smaldino, S.E (1999). Instructional Media and Technology for Learning. Upper Saddle Rive, NJ: Pearson Education, Inc.

Idris, K., dan Yang, K. (2015). Analysis of tasks in statistics textbooks for future English teachers based on statistical cognitions. Proceding of ICMI, (hal. 321-327).

Iftakhar, S. (2016). Google Classroom: What Works And How?. Journal of Education and Social Sciences, 3(2). 12-18.

Kalobo, L. (2016). “Teachers' Perceptions of Learners' Proficiency in Statistical Literacy, Reasoning and Thinking". African Journal of Research in Mathematics, Science and Technology Education, (3), pp.225-233.

Kusumah, J. W., dan Hamidah. (2020). Perbandingan Hasil Belajar Matematika Dengan Penggunaan Platform Whatsapp Group Dan Webinar Zoom Dalam Pembelajaran Jarak Jauh Pada Masa Pandemik Covid 19. Jurnal Ilmiah Pendidikan Matematika, 5(1), 97106.

Lasmiyati dan Harta, I. (2014). Pengembangan Modul Pembelajaran untuk Meningkatkan Pemahaman Konsep dan Minat SMP. PYTHAGORAS: Jurnal Pendidikan Matematika, 9 (2), 161-174. Diambil dari: : http://journal.uny.ac.id/index.php/pythagoras

Lee, C. (1998). An Assessment Of The PACE Strategy For An Introductory Statistics Course. Proceedings Of The 5th International Conference On Teaching Statistics. 1214-1220.

Jin, L., Kim, Y. J., McGhee, M., dan Reiser, R. (2011). Statistical Reasoning Skills And Attitude: The Effect Of Worked Examples. Proceedings of AECT International Convention, pp.105-110.

Lovett, M. (2001).“A Collaborative Convergence on Studying Reasoning Processes.A Case Study in Statistics".In D Klahr and S. Carver (Eds).Cognition and Instruction TwentyFive Years of Progress (p 347-384). Mahwah: NJ Lawrence Erlbaum.

Mailizar, Almanthari, A., Maulina, S., dan Bruce, S. (2020). Secondary School Mathematics Teachers' Views on E-learning Implementation Barriers during the COVID-19 Pandemic: The Case of Indonesia. EURASIA Journal of Mathematics, Science and Technology Education, 16(7). https://doi.org/10.29333/ejmste/8240

Munawaroh, I. (2019). Penggunaan Media Sosial Sebagai Upaya Meningkatkan Hasil Belajar Matematika Peserta Didik Kelas Ix Di SMP Negeri 1 Sindangkasih Kabupaten Ciamis Tahun Pelajaran 2017/2018. Prosiding Seminar Nasional \& Call For Papers Program Studi Magister Pendidikan Matematika Universitas Siliwangi, Tasikmalaya, 19 Januari 2019 
Pearce, A. R., dan Cline, R. L. (2006). Teaching the Statistics Laboratory - Keep up the PACE. American Journal of Psychological Research, 2(1), 1-7.

Rumsey, D. (2002). Statistical Literacy as a Goal for Introductory Statistics Courses.Journal of Statistics Education, 10(3).[Online]. Tersedia: www.amsat.org/publicatins/jse/v10n3/rumsey2.html.

Smith, dan Harlan.(2009). Learning to teach with problem-based learning. Active Learning in Higher Education, Vol 10(2): 138-153.

Sukestiyarno, Y. L. (2020). Metode Penelitian Pendidikan. Semarang: UNNES PRESS.

Sutame, K. (2019). Kulwa Malming; Media Belajar Mandiri Matematika Sekolah Kejuruan. Lentera Jurnal Ilmiah Kependidikan, 14 (2), 97-107.

Tudor, G. E. (2006). Teaching Introductory Statistics Online - Satisfying the Students. Journal of Statistics Education, 14 (3). htps://doi.org/10.1080/10691898.2006.11910591.

Türegün, Mehmet.(2014).A Four-Pillar Design To Improve The Quality Of Statistical Reasoning And Thinking In Higher Education.TOJQIH - The Online Journal of Quality in Higher Education, 1(1), 1-8.

WHO. (2020). Coronavirus disease (COVID-19) pandemic. 2020, from https://www.who.int/

Yang, D. (2017). Instructional strategies and course design for teaching statistics online: perspectives from online students. International Journal of STEM Education, 4(34).

Yaniawati, P. (2020). Strategi Pemanfaatan Teknologi dalam Home Based Learning. Webinar Program Studi Magister Pendidikan Matematika Pascasarjana Universitas Pasundan.

Yusuf, Y., Jaenudin, A., dan Rosita, N. T. (2016). Pengaruh Penggunaan Modul Berbantuan Program R terhadap Kemampuan Penalaran Statistik. Prosiding Seminar Nasional Matematika X Universitas Negeri Semarang 2016 (499 - 504). Semarang, Jawa Tenga 